\title{
JNTIP
}

Jurnal Nutrisi Ternak Tropis dan IImu Pakan

Jurnal Nutrisi Ternak Tropis dan Ilmu Pakan

Tersedia online di : jurnal.unpad.ac.id/jnttip

1(1):6-15, Desember 2019

\section{PROFIL ENZIM TRANSAMINASE AYAM RAS PETELUR YANG DIBERI KITOSAN IRADIASI}

\section{The Profile of Laying Hens Transaminase Adminestered Chitosan Irradiated}

\author{
Arvina Dinana ${ }^{1}$, Diding Latipudin², Darmawan Darwis ${ }^{3}$, Andi Mushawwir ${ }^{2}$ \\ ${ }^{1}$ Program Sarjana Ilmu Peternakan, Fakultas Peternakan, Universitas Padjadjaran \\ Kampus Jatinangor, Jl. Raya Bandung-Sumedang KM.21, Jatinangor-Sumedang, \\ Jawa Barat 45363 \\ ${ }^{2}$ Laboratorium Fisiologi Ternak dan Biokimia, Depertemen Nutrisi Ternak dan \\ Teknologi Pakan, Fakultas Peternakan, Universitas Padjadjaran, Bandung \\ Kampus Jatinangor, Jl. Raya Bandung-Sumedang KM.21, Jatinangor-Sumedang, \\ Jawa Barat 45363 \\ ${ }^{3}$ Pusat Aplikasi Isotop dan Radiasi (PAIR), Badan Tenaga Nuklir Nasional \\ Jl. Kuningan Barat, Mampang Prapatan, Jakarta 12710
}

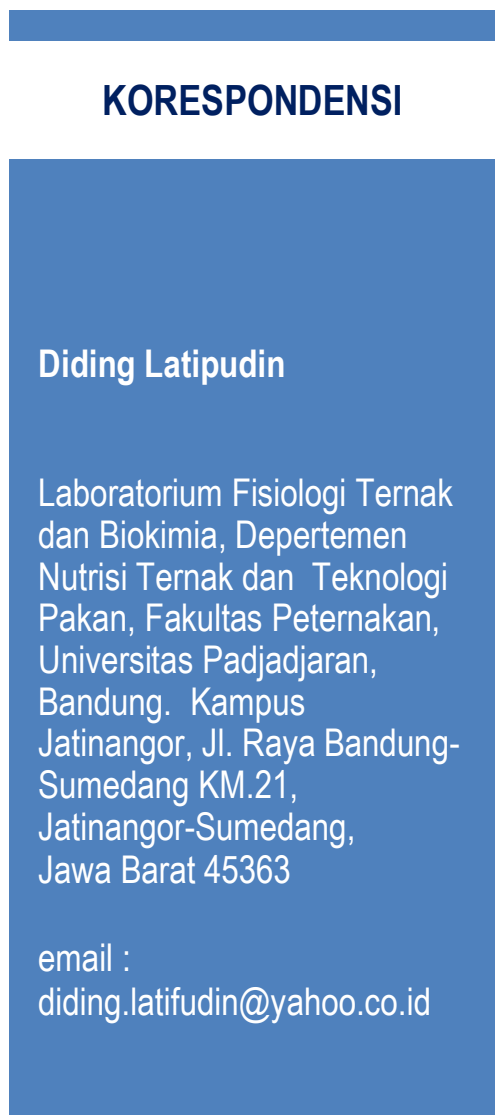

\begin{abstract}
ABSTRAK
Lima puluh ekor ayam ras peterlur fase layer telah digunakan dalam penelitian ini, selama tiga bulan, bertempat di salah satu peternakan ayam ras petelur, Desa Sukarapih, Kecamatan Sukasari, Kabupaten Sumedang, Jawa Barat. Analisis darah dilakukan di Laboratorium Fisiologi dan Biokimia Fakultas Peternakan Universitas Padjadjaran. Penelitian ini bertujuan untuk mengetahui pengaruh pemberian Kitosan Iradiasi terhadap profil enzim transaminase pada ayam ras petelur. Penelitian ini menggunakan metode eksperimental dengan uji ortogonal polinomial. Terdapat lima jenis perlakuan, $\mathrm{P} 0=$ ayam petelur yang tanpa diberi Kitosan, $\mathrm{P} 1=$ ayam petelur yang diberi Kitosan 150 ppm, P2 = ayam petelur yang diberi Kitosan 200 ppm, P3 = ayam petelur yang diberi Kitosan 250 ppm, dan P4 = ayam petelur yang diberi Kitosan 300 ppm. Berdasarkan hasil analisis statistik menunjukkan bahwa pemberian Kitosan iradiasi berbeda nyata $(\mathrm{p}<0,05)$ pada jumlah SGOT dan SGPT.
\end{abstract}

Kata Kunci: ayam; kitosan iradiasi; transaminase

\section{ABSTRACT}

This research was held during one month, started in August to September 2019 at layer farm, Sukarapih Village, Sumedang, West Java. The blood sample was analyzed at Physiology and Biochemical Laboratory Universitas Padjajaran Faculty of Animal Husbandry. This research 
was conducted to determine the effect of using chitosan irradiation on laying hens transaminase. This research is using an experimental method with orthogonal polynomial test. There are five kinds of treatment. $P O=$ laying hens without Chitosan, $P 1=$ laying hens with granting Chitosan 150 ppm, P2 = laying hens with granting Chitosan 200 ppm, P3 = laying hens with granting Chitosan 250 ppm, and P4 = laying hens with granting Chitosan 300 ppm. Based on the statistic analysis result, it indicates that the Chitosan Irradiation gives a real difference ( $p>0.05)$ on SGOT and SGPT levels.

Keywords: laying hens; chitosan irradiation; transaminase

\section{PENDAHULUAN}

Ayam ras petelur merupakan salah satu komoditas peternakan yang berkembang sangat pesat. Hal ini dikarenakan produksi ayam ras petelur yang cukup tinggi jika di tempatkan pada lingkungan kandang yang ideal, yaitu pada temperatur $20-25^{\circ} \mathrm{C}$. Input Produksi perlu diperhatikan agar produksi tetap optimal. Input produksi meliputi beberapa unsur yaitu makanan pada ayam yang memenuhi kebutuhan pokoknya, selain itu perlu juga diperhatikan unsur kesehatan dan pengendalian penyakit pada ayam.

Tatalaksana pakan yang kurang baik dapat menjadi sumber penyakit bagi ternak. Penyimpanan bahan-bahan pakan yang tidak memenuhi standar, menjadi sumber pertumbuhan jamur-jamur patogen. Cemaran jamur patogen ini berdampak negatif terhadap histologi jaringan liver, yang dipicu oleh konsentrasi aflatoksin yang berlebih. Hasil penelitian yang dilaporkan Rachmawati (2005), menunjukkan bahwa bahan pakan di Indonesia $50 \%$ bahan pakan dalam bentuk jagung dan $90 \%$ bahan pakan ternak unggas terkontaminasi mikotoksin.

Mikotoksin (aflatoksin) dari jamur patogen menyebabkan kerusakan terhadap histologi jaringan liver. Diketahui bahwa paparan mikotoksin (aflatoksin) secara terus menerus menyebabkan proses detoksifikasi oleh sel-sel liver secara terus menerus, pada akhirnya terjadi kerusakan dan atau kematian sel-sel. Kondisi berdampak terhadap peningkatan migrasi enzim-enzim pemindah gugus amin (transaminase) baik Serum Glutamat Oksaloasetat Transaminase (SGOT) (Mushawwir dkk., 2018) maupun Serum Glutamat Piruvat Transaminase
(SGPT) kedalam sistim sirkulasi darah (Mushawwir dan Latipudin, 2011).

Pencegahan dampak buruk jamur patogen dengan pemberian antibiotik sintetik, justru menambah beban bagi liver dalam melakukan detoksifikasi zat-zat sintetik. Diperlukan feed additive alami untuk menanggulangi masalah ini. Salah satu upaya yang dapat dilakukan dengan pemberian kitosan. Kitosan merupakan sebuah kitin deasetilasi, eksoskeleton artropoda seperti kepiting, udang, serangga, dan makhluk laut lainnya dalam keluarga crustacea (Crini, 2005). Kitosan telah dikembangkan menjadi kitosan iradiasi guna memaksimalkan fungsinya untuk ternak. kitosan iradiasi adalah hasil perkembangan kitosan melalui radiasi sinar gama.

Kitosan mengandung asam amino yang dapat meningkatkan proses anabolisme protein. Asam amino digunakan sebagai prekursor dalam proses anabolisme protein. Komponen yang terkandung dalam kitosan diketahui bersifat antibakteri dan juga antioksidan. Pemberian kitosan dalam ransum ayam ras petelur diharapkan dapat mengontrol penyakit pada ayam khususnya pada organ dalam seperti penyakit hati. Terdapat dua jenis enzim pada ayam sebagai indikator penyakit pada organ dalam yaitu Serum Glutamat Oksaloasetat Transaminase (SGOT) dan Serum Glutamat Piruvat Transaminase (SGPT). SGOT berfungsi sebagai indikator dan evaluasi kerja hati (Mushawwir, 2015) serta otot jantung dan memantau efek obat yang hepatotoksik dan nefrotoksik, sedangkan SGPT berfungsi sebagai indikator kerja hati, memantau efek obat yang hepatotoksik, membedakan ikterus hemolitik dengan ikterus karena penyakit hati. Dengan demikian, 
kajian pemberian kitosan iradiasi terhadap enzim transaminase pada ayam ras petelur penting dilakukan melalui penelitian ini.

\section{METODE PENELITIAN}

\section{Ternak Percobaan}

Ternak percobaan yang digunakan untuk penelitian ini adalah ayam petelur fase layer sebanyak 50 ekor (dengan rata-rata bobot badan 1800 gram) dari total populasi 1300 ekor yang berumur 29 bulan. Sampel tersebut dipelihara dalam kandang tipe semi close house dengan bentuk battery individual. Penelitian ini telah dilaksanakan dengan menggunakan teknik rancangan acak lengkap. Terdiri dari lima (5) perlakuan penambahan kitosan iradiasi dengan sepuluh (10) ulangan. Kelima perlakuan tersebut, yaitu:

Perlakuan 0 : Tanpa pemberian kitosan iradiasi

Perlakuan 1 : Kitosan iradiasi 150 ppm dalam air minum

Perlakuan 2 : Kitosan iradiasi 200 ppm dalam air minum

Perlakuan 3 : Kitosan iradiasi 250 ppm dalam air minum

Perlakuan 4 : Kitosan iradiasi 300 ppm dalam air minum

\section{Pembuatan Larutan Kitosan Iradiasi}

Kitosan yang digunakan dalam penelitian ini yaitu kitosan yang telah diiradiasi dengan menggunakan teknik radiasi nuklir. Berat molekul kitosan iradiasi 30-50 kD. Kitosan hasil radiasi dalam bentuk cairan, diperoleh dari Pusat Aplikasi Isotop dan Radiasi (PAIR), Badan Tenaga Nuklir Indonesia (BATAN), Pasar Jumat Jakarta. Larutan kitosan dibuat dengan cara melarutkan kitosan induk sebanyak $3 \mathrm{~mL}, 4$ $\mathrm{mL}, 5 \mathrm{~mL}$, dan $6 \mathrm{~mL}$ ke dalam air minum hingga $1 \mathrm{~L}$, sehingga diperoleh konsentrasi larutan kitosan iradiasi masing-masing 150 ppm, 200 ppm, 250 ppm dan 300 ppm. Kemudian diberikan kepada ternak percobaan sesuai dengan perlakuan.

\section{Analisis Statistika}

Data respon penelitian telah dianalisis dengan menggunakan metode polynomial orthogonal. Suatu derajat polynomial ke-n digunakan untuk mengetahui hubungan antara peubah respon $\mathrm{Y}$ dan peubah predictor $\mathrm{X}$ diujikan sebagai berikut :

$$
\begin{aligned}
& \mathrm{Y}=\alpha+\beta_{1} \mathrm{X}+\beta_{2} \mathrm{X}^{2}+\ldots+\beta_{\mathrm{n}} \mathrm{X}^{\mathrm{n}} \\
& \text { Perhitungan untuk mendapatkan }
\end{aligned}
$$

koefisien polynomial orthogonal untuk derajat polynomial pertama (linier), derajat polynomial kedua (kuadratik) dan derajat polynomial ketiga (kubik), sebagai berikut :

$$
\begin{gathered}
\mathrm{L}=\mathrm{a}+\mathrm{X}_{1} \\
\mathrm{Q}_{1}=\mathrm{b}+\mathrm{cX} \mathrm{X}_{1}+\mathrm{X}_{\mathrm{i}}^{2} \\
\mathrm{C}_{1}=\mathrm{d}+\mathrm{eX}_{1}+\mathrm{fX}_{1}^{2}+\mathrm{X}_{1}^{2}
\end{gathered}
$$

Selanjutnya dianalisis dengan menggunakan uji contras orthogonal.

Kontras ber-db tunggal merup-

kan fungsi linear (L) dari jumlah-jumlah perlakuan:

$\mathrm{L}=\mathrm{TC}_{\mathrm{i}} \mathrm{J}_{\mathrm{i}}=\mathrm{C}_{1} \mathrm{~J}_{1}+\mathrm{C}_{2} \mathrm{~J}_{2}+\ldots+\mathrm{C}_{\mathrm{t}} \mathrm{J}_{\mathrm{t}}$

Dimana:

$\mathrm{C}_{\mathrm{i}}=$ koefisien kontras ke-i

$\mathrm{J}_{\mathrm{i}}=$ jumlah nilai pengamatan ke-i

$\mathrm{t}=$ banyaknya perlakuan jumlah koefisien kontras $\left(\mathrm{TC}_{\mathrm{i}}\right)=0$

$\mathrm{r}$ = jumlah lokal kontrol/ulangan

JK kontras linear (JKL) ber-db tunggal dihitung sebagai berikut:

$$
\begin{gathered}
J K L=\frac{L^{2}}{r\left(T C_{i}^{2}\right)} \frac{L^{2}}{r K} \\
\mathrm{~K}=\mathrm{TC}_{\mathrm{i}}^{2}
\end{gathered}
$$

Dua kontras ber-db tunggal dikatakan orthogonal bila jumlah perkalian silang (JPS) dari koefisien keduanya $=0$, sebagai berikut:

$$
\begin{aligned}
& \mathrm{L}_{1}=\mathrm{C}_{11} \mathrm{~J}_{1}+\mathrm{C}_{12} \mathrm{~J}_{2}+\ldots+\mathrm{C}_{1 \mathrm{t}} \mathrm{J}_{\mathrm{t}} \\
& \mathrm{L}_{2}=\mathrm{C}_{21} \mathrm{~J}_{1}+\mathrm{C}_{22} \mathrm{~J}_{2}+\ldots+\mathrm{C}_{2 \mathrm{t}} \mathrm{J}_{\mathrm{t}}
\end{aligned}
$$

JPS $\quad=\mathrm{C}_{11} \mathrm{~J}_{21},+\mathrm{C}_{12} \mathrm{~J}_{22}+\ldots+\mathrm{C}_{1 \mathrm{t}} \mathrm{J}_{2 \mathrm{t}}=0$

Kemudian suatu grup kontras $p$ berderajat bebas tunggal dimana $\mathrm{p}>2$ ) dikatakan orthogonal mutual. Jika setiap pasangan dan semua pasangan kontras yang ada di dalam grup ini bersifat ortogonal. 


\section{HASIL DAN PEMBAHASAN}

Pengaruh pemberian berbagai kitosan iradiasi dalam air minum terhadap kadar Serum Glutamat Oksaloasetat Transaminase (SGOT) plasma darah ayam ras petelur, berdasarkan hasil penelitian dapat dilihat pada Tabel 1.

Hasil uji polynomial orthogonal menunjukan bahwa pemberian kitosan iradiasi berpengaruh nyata terhadap kadar SGOT plasma darah ayam ras petelur $(\mathrm{P}<0,05)$. Berdasarkan hasil penelitian menunjukkan bahwa semakin tinggi level pemberian kitosan iradiasi menyebabkan penurunan kadar SGOT dengan signifikan. Hasil uji beda contras orthogonal (Tabel 1) menunjukkan rata-rata kadar SGOT plasma darah ayam ras petelur berbeda nyata $(\mathrm{P}<0,05)$ pada masing-masing kelompok perlakuan.

Pada Tabel 1, tampak bahwa rata-rata kadar SGOT plasma darah ayam ras petelur tanpa pemberian kitosan iradiasi $(113,66$ IU/L), berbeda nyata paling tinggi $(\mathrm{P}<0,05)$ dibandingkan rata-rata kadar SGOT plasma darah kelompok ayam ras petelur yang diberi kitosan iradiasi sebanyak 150 ppm, 200 ppm, $250 \mathrm{ppm}$ dan $300 \mathrm{ppm}$, yaitu masing masing 83,20 IU/L; 63,73 IU/L; 48,36 IU/L dan 35,88 IU/L. Perbedaan rata-rata kadar SGOT yang nyata $(\mathrm{P}<0,05)$ juga terjadi antar kelompok ayam yang diberi perlakuan level kitosan iradiasi (Tabel 3). Glutamic axoaloacetic amino- transferase (GOT) serum atau serum aspartat transferase
(AST), merupakan salah satu enzim yang sering dikaitkan dengan kerusakan atau matinya sel hati. Enzim ini mengkatalis pemindahan bolak balik gugus amino antara asam amino aspartat dengan asam $\alpha$ ketoglutarat (Briefs, 1992). Hati merupakan organ yang paling banyak mengandung enzim aspartat transferase (AST). Adanya kerusakan pada hati dapat ditunjukan oleh naiknya kadar enzim AST atau SGOT (Widmann, 1985) atau karena adanya kerusakan atau perbaikan jaringan hati, maka hati akan meningkatkan pengeluaran enzim AST (Focus On Hepatitis Internasional, 1997).

Penurunan rata-rata kadar SGOT seiring dengan bertambahnya konsentrasi pemberian kitosan iradiasi dalam air minum, dapat diduga efektifitasnya melalui analisis kolerasi regresi. Penurunan kadar SGOT tersebut dipengaruhi oleh level pemberian kitosan sebesar $98,55 \%$ atau koefisen determinasinya 0,9855 . Terdapat derajat hubungan yang sangat tinggi antara peningkatan level pemberian kitosan iradiasi dengan penurunan kadar SGOT plasma darah, yaitu r=0,993 (Gambar 1).

Berdasarkan analisis kolerasi regresi besarnya penurunan kadar SGOT dapat diduga melalui persamaan atau model prediksi yaitu $\mathrm{y}=116,48-0,264 \mathrm{x}$. Berdasarkan model pendugaan tersebut dapat dijelaskan bahwa penambahan sebanyak 0,264 ppm kitosan iradiasi menyebabkan

Tabel 1. Hasil Uji Beda Contras Orthogonal terhadap Rata-Rata Kadar SGOT Ayam Ras Petelur dengan Pemberian Kitosan Iradiasi

\begin{tabular}{ccc}
\hline Perlakuan & Rata-rata SGOT (IU/L) & Uji Kontras Ortogonal* \\
\hline P0 & 113,66 & $\mathrm{a}$ \\
P1 & 83,20 & $\mathrm{~b}$ \\
P2 & 63,73 & $\mathrm{c}$ \\
P3 & 48,36 & $\mathrm{~d}$ \\
P4 & 35,88 & $\mathrm{e}$
\end{tabular}

Keterangan: * Notasi huruf yang berbeda menunjukan perbedaan yang nyata $(\mathrm{P}<0,05)$

P0 :Tanpa pemberian kitosan iradiasi; P1 : Kitosan iradiasi 150 ppm dalam air minum; P2 : Kitosan iradiasi 200 ppm dalam air minum; P3: Kitosan iradiasi 250 ppm dalam air minum; P4 : Kitosan iradiasi 300 ppm dalam air minum 
penurunan kadar SGOT sebanyak 1 IU/L plasma darah.

Pengaruh pemberian berbagai kitosan iradiasi dalam air minum terhadap kadar Serum Glutamat Piruvat Trans-aminase
$(\mathrm{P}<0,05)$ pada masing-masing kelompok perlakuan.

Pada Tabel 2, tampak bahwa rata-rata kadar SGPT plasma darah ayam ras petelur tanpa pemberian kitosan iradiasi $(155,48$

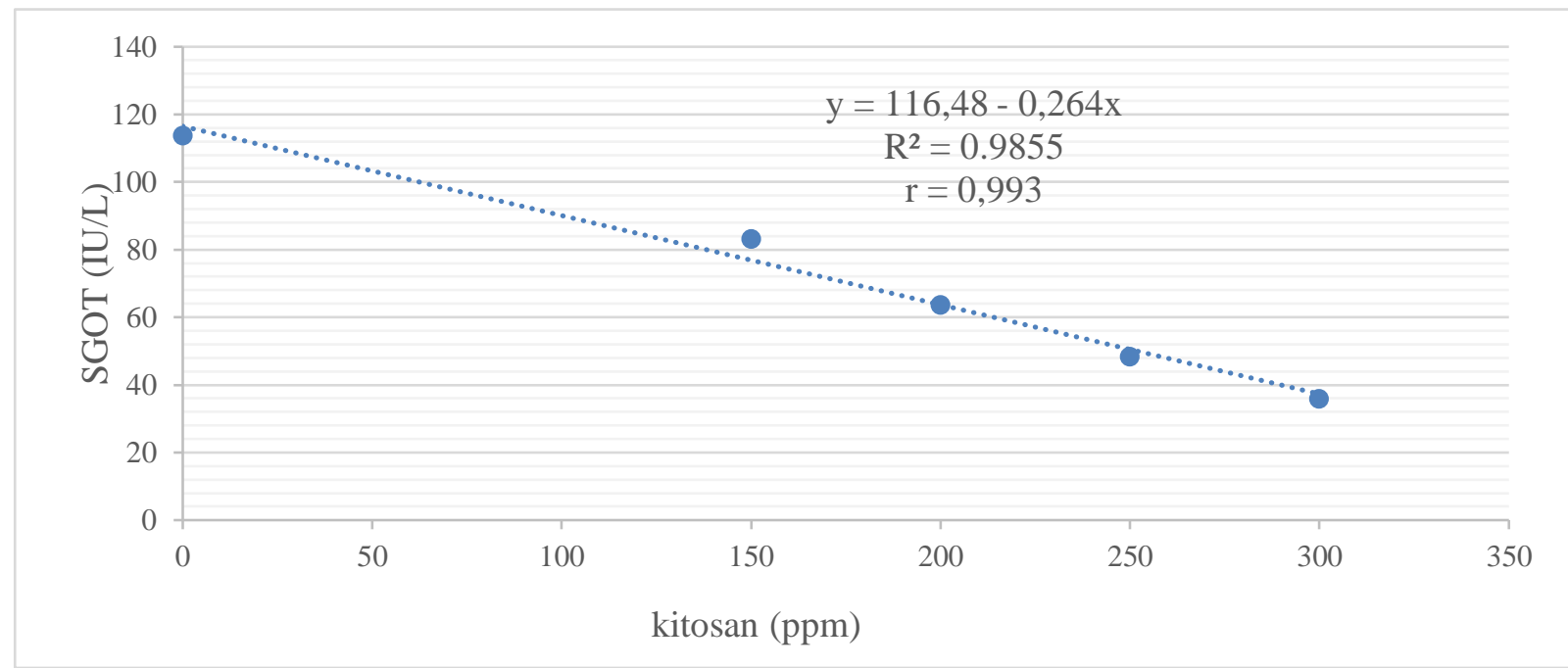

Gambar 1. Grafik Analisis Kolerasi Regresi Kadar SGOT Ayam Ras Petelur dengan Pemberian Kitosan Iradiasi

(SGPT) plasma darah ayam ras petelur, berdasarkan hasil penelitian dapat dilihat pada Tabel 2.

Hasil uji polynomial orthogonal menunjukan bahwa pemberian kitosan iradiasi berpengaruh nyata terhadap kadar SGPT plasma darah ayam ras petelur $(\mathrm{P}<0,05)$. Berdasarkan hasil penelitian menunjukkan bahwa semakin tinggi level pemberian kitosan iradiasi menyebabkan penurunan kadar SGPT dengan signifikan. Hasil uji beda contras orthogonal (Tabel 2) menunjukkan rata-rata kadar SGPT plasma darah ayam ras petelur berbeda nyata
IU/L), berbeda nyata paling tinggi $(\mathrm{P}<0,05)$ dibandingkan rata-rata kadar SGPT plasma darah kelompok ayam ras petelur yang diberi kitosan iradiasi sebanyak 150 ppm, 200 ppm, $250 \mathrm{ppm}$ dan $300 \mathrm{ppm}$, yaitu masing masing 120,23 IU/L; 84,77 IU/L; 59,95 IU/L dan 26,59 IU/L. Perbedaan rata-rata kadar SGPT yang nyata $(\mathrm{P}<0,05)$ juga terjadi antar kelompok ayam yang diberi perlakuan level kitosan iradiasi (Tabel 1).

Penurunan rata-rata kadar SGPT seiring dengan bertambahnya konsentrasi pemberian kitosan iradiasi dalam air minum, dapat diduga efektifitasnya melalui analisis kolerasi regresi. Penurunan kadar SGPT

Tabel 2. Hasil Uji Beda Contras Orthogonal terhadap Rata-Rata Kadar SGPT Ayam Ras Petelur dengan Pemberian Kitosan Iradiasi

\begin{tabular}{ccc}
\hline Perlakuan & Rata-rata SGPT (IU/L) & Uji Kontras Ortogonal* \\
\hline P0 & 155,48 & $\mathrm{~A}$ \\
P1 & 120,23 & $\mathrm{~B}$ \\
P2 & 84,77 & $\mathrm{C}$ \\
P3 & 59,95 & $\mathrm{D}$ \\
P4 & 26,59 & $\mathrm{E}$ \\
\hline
\end{tabular}

Keterangan: * Notasi huruf yang berbeda menunjukan perbedaan yang nyata $(\mathrm{P}<0,05)$ 
tersebut dipengaruhi oleh level pemberian kitosan sebesar 91,28\% atau koefisen determinasinya 0,9128 . Terdapat derajat hubungan yang sangat tinggi antara peningkatan level pemberian kitosan iradiasi dengan penurunan kadar SGPT plasma darah, yaitu $\mathrm{r}=0,955$ (Gambar 2). dalam plasma darah menjadi indikator kerusakan sel-sel atau jaringan hati.

Berdasarkan hasil penelitian ini tampak bahwa SGOT dan SGPT terdeteksi di dalam sampel plasma darah ayam percobaan. Konsentrasi keduanya lebih tinggi dalam plasma darah ayam percobaan tanpa

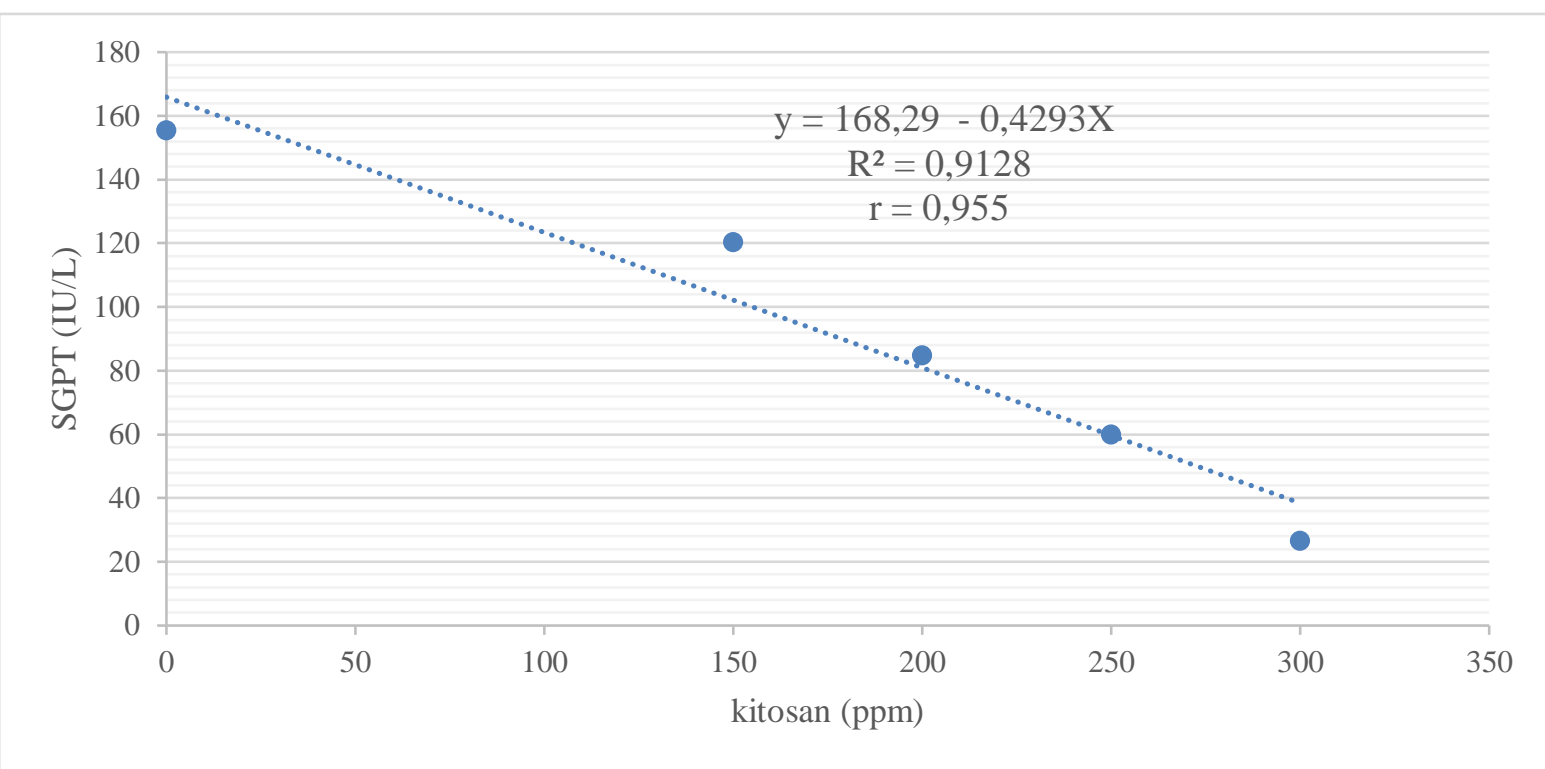

Gambar 2. Grafik Analisis Kolerasi Regresi Kadar SGPT Ayam Ras Petelur dengan Pemberian Kitosan Iradiasi

Berdasarkan analisis kolerasi regresi besarnya penurunan kadar SGPT dapat diduga melalui persamaan atau model prediksi yaitu $\mathrm{y}=168,29-0,4293 \mathrm{x}$. Berdasarkan model pendugaan tersebut dapat dijelaskan bahwa penambahan sebanyak 0,4293 ppm kitosan iradiasi menyebabkan penurunan kadar SGPT sebanyak 1 IU/L plasma darah. Serum Glutamat Oksaloasetat Transaminase (SGOT) dan Serum Glutamat Piruvat Transaminase (SGPT) keduanya, berfungsi mengkatalis reaksi asaminase. SGOT dan SGPT merupakan enzim mitokondria yang berfungsi mengkatalis pemindahan bolak balik gugus amino dari asam aspartate ke asam $\alpha$-oksaloasetat membentuk asam glutamat dan oksaloasetat (Price and Wilson, 1995; Mushawwir dan Latipudin, 2012)). Kedua enzim tersebut umumnya berada dan bekerja di dalam sel-sel liver (hati), oleh karena itu keberadaannya di pemberian kitosan iradiasi. Hasil ini mampu menunjukkan efektifitas molekul-molekul kitosan hasil iradiasi untuk memperbaiki dan membangun kembali sel-sel dan jaringan hati.

Apabila dikaitkan dengan hasil penelitian Rachmawati (2005) bahwa 90\% bahan pakan unggas di Asia Tenggara tercemar aflatoksin dan bahan pakan jagung di Indonesia tercemar lebih dari $50 \%$. Ini berarti potensi kerusakan sel-sel hati unggas di Indonesia yang disebabkan dari aflatoksin di bahan pakan adalah sangat tinggi resikonya.

Hati merupakan salah satu organ yang paling terpengaruh akibat cemaran aflatoksin. Salah satu mekanisme kerja aflatoksin adalah mencegah sintesis RNA dihati sehingga menyebabkan kerusakan hati ternak. Keracunan akut oleh aflatoksin dihati berdampak terhadap kegagalan metabolisme karbohidrat, lemak dan sintesis protein, pada 
akhirnya mengakibatkan kerusakan sel-sel dan jaringan hati (Dhanasekaran et al., 2011).

Selain itu, dampak negatif yang ditimbulkan oleh aflatoksin adalah stress oksidatif, ditunjukkan dengan meningkatnya peroksidasi lemak dan menurunkan antioksidan enzimatis dan non-enzimatis (ElGibaly et al., 2003). Dampak kerusakan selsel hati oleh aflatoksin menyebabkan kerusakan membran hingga kematian sel. Oleh sebab itu, enzim-enzim yang bekerja di dalam sel-sel hati mengalami migrasi ke sistem pembuluh darah. Fakta ini menyebabkan kadar enzim trasaminase, baik SGOT maupun SGPT meningkat kadarnya secara signifikan $(\mathrm{P}<0,05)$ di dalam plasma darah dengan pemberian kitosan 150 sampai $250 \mathrm{ppm}$. Begitu pula terhadap kelompok ayam petelur percobaan tanpa pemberian kitosan iradiasi pada air minumnya (Tabel 1 dan 2).

Hasil-hasil penelitian terdahulu mengenai dampak aflatoksin dalam ransum ayam telah banyak dilaporkan. David et al. (1994) menunjukkan sebuah diagram stimulasi aflatoksin B1 terhadap pensignalan protein yang menyebabkan kematian sel (Gambar 3). menyebabkan kematian sel. Dampak aflatoksin terhadap sel-sel hati juga menyebabkan kerusakan oksidatif pada lipid dan lipoprotein yang merupakan komponen sel (Goodsell, 2001). Juga dilaporkan bahwa kerusakan oksidatif menyebabkan munculnya radikal-radikal bebas. Aktivitas radikal bebas menyebabkan kerusakan lipid (Chen et al., 2009), enzim (Burdick et al., 2011), asam nukleat dan protein (Prieto et al., 2008) hingga kerusakan sel dan DNA (Shin et al., 2010).

Pemberian kitosan iradiasi, terbukti efektif mengurangi atau menanggulangi kematian sel, baik sebagai dampak langsung aflatoksin, maupun dampak tidak langsung yaitu peningkatan radikal bebas yang menyebabkan kematian sel. Efektifitas kitosan iradiasi dalam mencegah kerusakan sel-sel hati tampak optimum dengan pemberian 300 ppm kitosan iradiasi dalam air minum, ditandai dengan penurunan kadar SGOT sebesar 35,88 (Tabel 1) dan SGPT 26,59 (Tabel 2), berbeda nyata lebih rendah $(\mathrm{P}<0,05)$ dibandingkan kadar SGOT dan SGPT plasma darah kelompok ayam ayam tanpa pemberian kitosan iradiasi. Ini berarti migrasi SGOT dan SGPT kedalam sistem

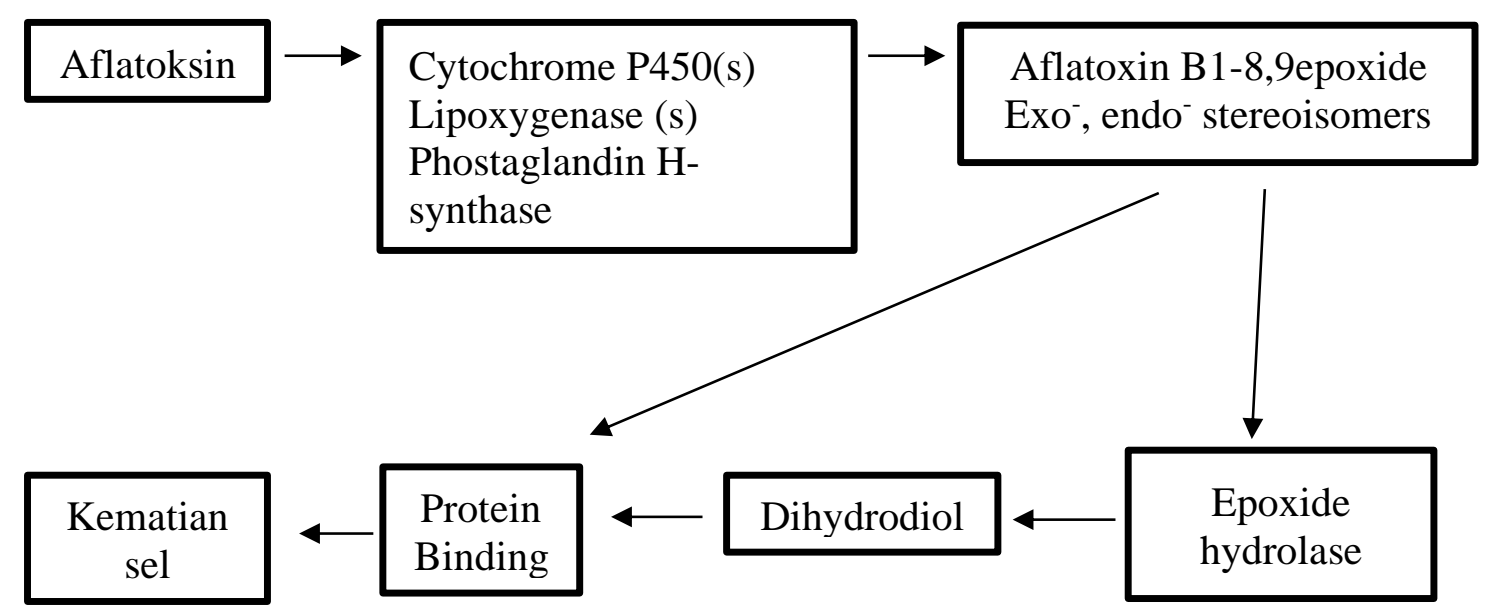

Gambar 3. Bagan Alur Pensignalan Protein yang Dihambat oleh Aflatoksin Sehingga Terjadi Kematian Sel

Berdasarkan Gambar 3 tampak bahwa aflatoksin mampun mendikte pensignalan protein dan menstimulasi protein-protein yang terlibat secara langsung sehingga pembuluh darah sebagai akibat kerusakan sel-sel hati mengalami penurunan yang signifikan. 
Hasil penelitian ini membuktikan bahwa molekul kitosan iradiasi dengan berat 30-50 kD, mampu berinteraksi dan membangkitkan signal molekul di dalam sel. Selain menstimulasi signal yang menstimulasi perbaikan sel-sel, kitosan iradiasi mampu menanggulangi dampak negatif radikal-radikal bebas terutama dari kelompok spesies oksigen bervalensi satu (reactive oxygen species (ROS).

Mekanisme biokimiawi kitosan dalam mencegah atau menanggulangi dan bahkan memperbaiki kembali sel-sel hati, telah dilaporkan oleh peneliti-peneliti sebelumnya. Carroll et al. (2016) menunjukkan kemampuan kitosan mencegah aktifasi ROS melalui pengaktifan Cyclic Guanin Monophospat-Adenyn Monophospat Synthase (cGAS) dan Stimulator of Interferon Genes (STING) di dalam sel-sel dendrit. Aktifasi cGAS-STING menginduksi aktifasi inteferon dependent tipe-1 (I IFN-dependent), kemudian sel-sel dendrit menjadi aktif. Selanjutnya Blaauboer et al. (2015) dan Cai et al. (2014) melaporkan bahwa aktifasi selsel dendrit meningkatkan respon polarisasi protein sel-sel T-helper 1 (TH1). Aktivasi Th1 meningkatkan interferon gamma (IFN $\gamma$ ), sehingga menstimulasi imunoglobulin $G$ (IgG) di dalam sitoplasma. Peningkatan signal jalur ini mampu mencegah kerusakan sel (Bueter et al., 2014).

Mekanisme lain sebagai dampak pemberian kitosan dalam mencegah kerusakan sel-sel ditunjukkan dengan kemampuan kitosan mengaktifkan realis ATP (Gehrke et al., 2013), realis ATP menstimulasi pengaktifan nuklear reseptor ptotein 3 (NLRP3 inflamma-some) (Lin et $a l .$, 2014). Signal dari NLRP3 menstimulasi ekspresi gen interleukin-1 $\beta$ (IL-1 $\beta$ ) dan interferon gamma (IFN $\gamma$ ). Peningkatan kadar interleukin-1 $\beta$ (IL-1 $\beta$ ) dan interferon gamma (IFN $\gamma$ ) mencegah ROS dalam menghambat Cyclic Guanin Mono-phospat-Adenyn Monophospat Synthase (cGAS) dan Stimulator of Interferon Genes (STING) (Dubensky et al., 2013). Dengan demikian, kerusakan sel-sel hati dapat ditanggulangi secara efektif dengan kitosan iradiasi.

\section{KESIMPULAN DAN SARAN}

Berdasarkan hasil penelitian disimpulkan bahwa, pemberian kitosan iradiasi dalam air minum dapat memperbaiki kadar SGOT dan SGPT darah ayam ras petelur, ditunjukkan dengan penurunan kadar SGOT dan SGPT plasma darah ayam ras petelur. Penggunaan kitosan iradiasi pada ayam ras petelur, disarankan menggunakan level 300 ppm dalam air minum agar konsentrasi kadar SGOT dan SGPT darah tidak meningkat.

\section{UCAPAN TERIMA KASIH}

Ucapan Terima Kasih disampaikan kepada seluruh pihak yang telah membantu penelitian ini, khususnya Adang Sudrajat (Laboran Lab. Fisiologi Ternak dan Biokimia Fapet Unpad). Penelitian hingga penulisan artikel ini telah dilaksanakan dengan kontribusi yang sama dengan seluruh tim yang terlibat seperti yang tercantum sebagai penulis dalam artikel ini.

\section{DAFTAR PUSTAKA}

Blaauboer, S.M., Mansouri, S., Tucker, H.R., Wang, H.L., Gabrielle, V.D., and Jin, L. 2015. The Mucosal Adjuvatnt Cyclic di-GMP Enhances Antigen Uptake and Selectively Activates Pinocytosis-Efficient Cell in Vivo. eLife 4:1-25.

Briefs, 1992. The Amazing Liver. Healing Edge Sciences a Professional Network for Health Practitioners and Their Patients.

Bueter, C.L., Lee, C.K., Wang, J.P., Ostroff, G.R., Specht, C.A., and Levitz, S.M. 2014. Spectrum and Mechanism of Inflammasome Activation by Chitosan. J. Immunol. 192: 5943-5951.

Burdick, N. C., J. A. Carroll, R. Randel, S. Willard, R. Vann, C. C. Chase, S. Lawhon, L. E. Hulbert, \& J. T. Welsh. 2011. Influence of Temperament and Transportation on Physiological and Endocrinological Parameters in Bulls. Livestock Sci. 139:213-221. 
Cai, X., Chiu, Y.H., and Chen Z.J. 2014. The cGAS-cGAMP-STING Pathway of Cytosolic DNA Sensing and Signaling. Molecular Cell. 54:289-296.

Carrol E.C., Jin, L., Mori, A., Wolf, M.N., Oleszycka, E., Moran, H.B.T.,

Promotes Celluler Immunity Via DNA Sensor Cgas-STING-Dependent Induction of Type I Interferons. Immunity. 44:1-12.

Chen, J., W. Q. Zhou, L. Feng, Y. Liu and J. Jiang. 2009. Effects of Glutamine on Hydrogen Peroxide-Induces Oxidative Damage in Intestinal Epithelial Cells of Jian Carp (Cyprinus carpio var. Jian). Aquaculture. 288:285-289.

Crini, G. 2005, Recent Developments in Polysaccharide-Based Materials Used as Adsorbents in Wastewater Treatment, Prog. Polym. Sci. 30: 38-70.

David, L., Eaton and Evan P. Gallagher. 1994. Mechanisms of Aflatoxin Carcinogenesis. Animal Reviews. 34:135-72.

Dhanasekaran D., S. Shanmugapriya S., Thajuddin N., and Panneerselvam A. 2011. Aflatoxins and Aflatoxicosis in Human and Animals, di dalam Aflatoxins Biochemistry and Molecular Biology. Dr. Ramon G. Guevara Gonzalez (Ed). http://www.Intechopen.com/ books/aflatoxinsbiochemistry-andmolecular-biology/aflatoxins-andaflatoxicosis-in-human-and-animals. Diunduh tanggal 2 Desember 2019.

Dubensky, T.W., Jr., Kanne, D.B., and Leong, M.L. 2013. Ratonae, Proggres and Development of Vaccines Utilizing STING-Activating Cyclic Dinucleotide Adjuvants. Ther. Adv. Vaccines. 1:131-143.

El-Gibaly, I., Meki, A.M., Abdel-Ghaffar, S.K., 2003. Novel B MelatoninLoadedchitosan Microcapsules: in Vitro Characterization and Antiapoptosis Efficacyfor Aflatoxin B1-Induced Apaptosis in Rat Liver. International Journal of Pharmacology. 260:5-22.
Mansouri, S., McEntee, C.P., Lambe, E., Agger, E.M., Andersen, P., Cunningham, C., Hertzog, P., Fitzgerald, K.A., Bowie, A.G., and Lavelle, E.C. 2016. The Vaccine Adjuvant Chitosan

[FHI] Focus on Hepatitis International. 1997. Laboratory Test. ALT (alanine Aminotranferase Serum).

Gehrke, N., Mertens, C., Zillinger, T., Wenzel, J., Bald, T., Zahn, S., Tüting, T., Hartmann, G., and Barchet, W. 2013. Oxidative Damage of DNA Confers Resistance to Cytosolic Nuclease TREX1 Degradation and Pontentiates STING-Dependent Immune Sensing. Immunity. 39:482495.

Goodsell, DS. 2001. The Molecular Perpective: Cytochrome P450. The Oncologist 6:205-206.

Lin, Y.C., Lou, P.J., and Young, T.H. 2014. Chitosan as an Adjuvant-Like Substrate for Dendritic Cell Culture to Enhace Antitumor Effect. Biomaterials 35, 8867-8875.

Mushawwir, A. dan D. Latipudin. 2011. Beberapa Parameter Biokimia Darah Ayam Ras Petelur Fase Grower dan Layer dalam Lingkungan "Upper Zonathermoneutral. J. Peternakan Indonesia. 13:191-198.

Mushawwir, A. dan D. Latipudin. 2012. Respon fisiologi thermoregulasi ayam ras petelur fase grower dan layer. Proseding seminar zootechniques for Indogeneous resources development, ISAA Fakultas Petenakan Universitas Diponegoro. Proceeding of National Seminar on Zootechniques. 1:23-27.

Mushawwir, A. 2015. Biokimi Nutrisi. Widya Padjadjaran, Bandung.

Mushawwir, A., N. Suwarno. A.A. Yulianti. 2019. Profil Malondialdehyde (MDA) dan Kreatinin Itik Fase Layer yang Diberi Minyak Atsiri Garlic Dalam Kondisi Cekaman Panas. J. Ilmu dan Industri Peternakan. 5:1-11.

Price, A.S and Wilson, L. M. 1995. Patofisiologi Konsep Klinis Proses- 
proses Penyakit. Jakarta:Penerbit Buku Kedokteran EGC.

Prieto, A. I., A. Jos, S. Pichardo, I. Moreno and A. M. Cameán. 2008. Protective Role of Vitamin E on the MicrocystinInduces Oxidative Stress in Tilapia Fish (Oreochromis niloticus). Environ. Toxicol. Chem. 27:1152-1159.

Rachamawati, S. 2005. Aflatoksin dalam Pakan Ternak Di Indonesia: Persyaratakan Kadar dan Pengembangan Teknik Deteksinya. Wartazoa. 15 : 26-37.

Shin, H.S., J. H. Yoo1, T. S. Min, J. Lee and C. Y. Choi. 2010. Effect of Quercetin on the Activity and mRNA Expression of Antioxidant Enzymes and Physiological Responses in Olive Flounder (Paralichthys olivaceus) Exposed to Cadmium. Asian-Aust. J. Anim. Sci. 23: 742 - 749.

Widmann, FK. 1985. Clinical Interpretation of Laboratory Test (9th ed). PG. Publish Singapore. 